\title{
von Hippel-Lindau Tumor Suppressor Protein and Hypoxia-Inducible Factor in Kidney Cancer
}

\author{
Mindy A. Maynard Michael Ohh \\ Department of Laboratory Medicine and Pathobiology, Faculty of Medicine, University of Toronto, \\ Toronto, Ont., Canada
}

\section{Key Words}

von Hippel-Lindau disease - Renal clear-cell carcinoma • von Hippel-Lindau tumor suppressor protein .

E3 ubiquitin ligase - Hypoxia-inducible factor · Hypoxia . Angiogenesis

\begin{abstract}
The development of hereditary von Hippel-Lindau (VHL) disease and the majority of sporadic kidney cancers are due to the functional inactivation of the $V H L$ gene. The product of the $\mathrm{VHL}$ gene, $\mathrm{PVHL}$, in association with elongins $B$ and $C$, cullin 2, and Rbx1 form an E3 ubiquitinligase complex VEC that targets the alpha subunits of hypoxia-inducible factor (HIF) for ubiquitination. Ubiquitin-tagged HIF- $\alpha$ proteins are subsequently degraded by the common $26 \mathrm{~S}$ proteasome. pVHL functions as the substrate-docking interface that specifically recognizes prolyl-hydroxylated HIF- $\alpha$. This hydroxylation occurs only in the presence of oxygen or normoxia. Thus, under hypoxia, HIF- $\alpha$ subunits are no longer subjected to degradation and are thereby able to dimerize with the common and constitutively stable $\beta$ subunits. The heterodimeric HIFs upregulate a myriad of hypoxia-inducible genes, triggering our physiologic response to hypoxia.
\end{abstract}

Inappropriate accumulations of HIF- $\alpha$ in VHL disease are believed to contribute to the pathogenesis via the upregulation of several of these HIF target genes. Our current molecular understanding of the roles of HIF and pVHL in the development of VHL-associated clear-cell renal cell carcinoma (CC-RCC) is the focus of this review.

Copyright $@ 2004$ S. Karger AG, Basel

\section{Hereditary Kidney Cancers}

Kidney cancer occurs at a frequency of 1 in 30,000 individuals $[1,2]$. Of the $4 \%$ of the cases that are hereditary, the most common form is CC-RCC, a highly vascular tumor derived from the epithelial cell of the proximal tubule $[3,4]$. A prevalent genetic alteration observed in hereditary and most sporadic (approximately 80\%) CCRCC is the inactivation of the tumor suppressor $V H L$ gene on chromosome $3 \mathrm{p} 25[5,6]$. Translocation of chromosome $3 \mathrm{p}$ to chromosomes $2,6,8$, or 11 is also observed in families predisposed to CC-RCC [7-9]. The breakpoint of chromosome 3 for the translocations observed in CCRCC frequently does not interrupt VHL gene, but may disrupt other putative tumor suppressor genes [10].

\begin{tabular}{ll}
\hline KARGER & ( ) 2004 S. Karger AG, Basel \\
0250-8095/04/0241-0001\$21.00/0 \\
$\begin{array}{l}\text { Fax +4161306 1234 } \\
\text { E-Mail karger@karger.ch } \\
\text { www.karger.com }\end{array}$ & $\begin{array}{l}\text { Accessible online at: } \\
\text { www.karger.com/ajn }\end{array}$
\end{tabular}

Michael Ohh

Department of Laboratory Medicine and Pathobiology, Faculty of Medicine

University of Toronto, 1 King's College Circle

Toronto, Ont. M5S 1A8 (Canada)

Fax +1 416978 5959, E-Mail michael.ohh@utoronto.ca 
Other hereditary syndromes that predispose patients to kidney cancer include tuberous sclerosis (TS), papillary type 1 RCC, hereditary leiomyoma RCC, Birt-HoggDubé syndrome, familial renal oncocytoma, and medullary carcinoma. TS patients have a germline mutation in either the $T S C 1$ or the $T S C 2$ tumor suppressor genes [11]. The products of these loci are hamartin and tuberin which interact cooperatively to regulate cell growth [12]. Papillary type $1 \mathrm{RCC}$ has been attributed to activating mutations in the proto-oncogene a-met, a receptor for hepatocyte growth factor (HGF) [13]. In hereditary leiomyoma patients, germline mutations of the fumarase gene followed by a second somatic inactivation of the remaining wildtype allele have been implicated in the pathogenesis of this papillary type 2 RCC [14]. Fumarase is a mitochondrial protein that functions in the Krebs cycle. The absence of functional fumarase may cause reduced oxidative phosphorylation and increased free radical formation [15]. Oxygen free radicals may activate the human HIF-1 (hHIF-1) transcription factor and subsequent downstream proliferative targets such as transforming growth factor $\alpha(\mathrm{TGF}-\alpha)$ [15]. Birt-Hogg-Dubé syndrome is caused by a mutation of the $B H D$ gene that encodes the novel protein folliculin and results in chromophobe renal tumors [16]. Medullary carcinoma is a rare aggressive neoplasm associated with sickle cell disease [17]. The pathogenesis may be partially attributed to hemoglobinopathy, leading to hypoxia in the renal medulla [18]. hHIF-1 and the angiogenic protein vascular endothelial growth factor (VEGF) are overexpressed in these tumors [18]. Nonpolyposis colon cancer Lynch type 2 can also predispose afflicted individuals to kidney cancer, specifically squamous cell carcinoma in the renal pelvis. Lynch type 2 patients have defects in the mismatch repair genes $M S H$ and $M L H 1[19,20]$. The etiology of familial renal oncocytoma, a benign glandular tumor, is unknown [10].

\section{von Hippel-Lindau Disease}

VHL disease is a rare inherited disorder that occurs at a frequency of 1 in 36,000 in the general population [21]. It is characterized by the development of cysts and tumors in multiple organ systems [21-24]. In the central nervous system, these may include hemangioblastomas of cerebellum, brainstem, and spinal chord. Retinal hemangioblastomas, endolymphatic sac tumors of the inner ear, pheochromocytomas, pancreatic islet cell tumors, epididymal (in males) and broad-ligament (in females) cystadenomas, and CC-RCC are also commonly associated with
VHL disease. VHL tumors are highly vascular due to the overexpression of angiogenic factors such as VEGF [25]. $\mathrm{CC}-\mathrm{RCC}$ is the main cause of morbidity and mortality in these patients [26].

CC-RCCs occur in VHL patients at a frequency of approximately $45 \%$, with a mean age at the time of detection of 39 years [27]. The patients usually possess multiple bilateral cysts and tumors in their kidneys which range in size, grade, and growth rate [27]. Typically, the smaller tumors are of lower grade and less invasive. Renal cysts in VHL patients are homozygous null for $V H L$ and may transition to a solid tumor type [4]. Thus, VHL represents a classical 'gatekeeper', the inactivation of which represents an early and requisite step in tumor development [28].

Genetically, VHL disease is autosomal recessive [21, $25,29]$. VHL kindreds have a single germline mutation in one of the two $V H L$ alleles. The somatic loss of the remaining wild-type $V H L$ allele initiates tumor development [30]. This somatic event occurs at a very high frequency, resulting in a high penetrance of VHL disease $(>90 \%)[21,31]$. Thus, clinically, VHL disease presents as an autosomal dominant disorder. The correlation between specific germline mutations of the $V H L$ gene and tumor phenotype has led to the classification of VHL disease [21]. Typically, type 1 patients have a frequent loss of the entire $V H L$ gene or a gross truncation of the protein product $\mathrm{pVHL}$, while type 2 patients usually possess missense mutations [32, 33]. Type 1 VHL patients have a low risk of developing pheochromocytomas, but present with other tumors, including hemangioblastomas of CNS and retina and CC-RCC. Type 2 patients have a high risk of developing pheochromocytomas and are further subdivided according to their predisposition to CC-RCC. Type $2 \mathrm{~A}$ patients are at low risk, type $2 \mathrm{~B}$ patients are at high risk, and type $2 \mathrm{C}$ patients develop pheochromocytomas exclusively. Pheochromocytoma may represent a gain of function for $\mathrm{pVHL}$ because the risk of a pheochromocytoma is very low in type I patients [34].

\section{VHL Tumor Suppressor Gene and pVHL}

The VHL gene on chromosome $3 \mathrm{p} 25$ in humans consists of only three exons [35-37]. Its promoter contains three positive regulatory regions. An Sp1-binding site at +1 to +11 significantly contributes to transcriptional activation of $V H L$ [38]. The two other positive regions ( -49 to -19 and -114 to -91 ) interact with yet unidentified transcription factors [38]. The VHL locus produces two tran- 
scripts that are translated into three proteins [39-42]. The first VHL mRNA contains exons $1-3$ and is translated into two proteins due to an internal translational initiation start site at codon 54 [39-42]. The larger product is a 213 amino acid protein of approximately $24-30 \mathrm{kD}$ $\left(\mathrm{pVHL}{ }^{30}\right)$, and the shorter is an $18-19 \mathrm{kD}$ isoform $\left(\mathrm{pVHL}{ }^{19}\right)$ of 160 amino acids [39-42]. At present, both are believed to be wild-type functional VHL proteins and are collectively referred to as pVHL. Accordingly, no tumor-derived mutations have been detected in the first 54 amino acid residues of $V H L[33,43]$. Both proteins when expressed in VHL-/- CC-RCC cells are capable of suppressing tumor formation in Nude/SCID mice [39, 41, $42,44]$. The second transcript translated into the third protein from the $V H L$ gene consists of exon 1, spliced directly to exon 3 , and is not capable of tumor suppression [5].

\section{pVHL Expression and Subcellular Localization}

pVHL is conserved across species and ubiquitously expressed in human fetal and adult tissues [45, 46]. Homozygous germline inactivation of $V H L$ is embryonic lethal due to a deficiency in placental vasculogenesis [47]. A conditional knockout of $V H L$ in the liver of mice causes steatosis and blood-filled vascular cavities, indicating its importance in regulating angiogenesis in adults [48]. The steatosis observed in the conditional knockout is due to an accumulation of fat in hepatocytes that is similar to that observed in the stroma of hemangioblastomas in VHL patients [48-51]. However, unlike in humans, mice heterozygous for $V H L$ are normal and do not develop tumors over their, albeit short, life span [47].

$\mathrm{pVHL}^{19}$ and $\mathrm{pVHL}^{30}$ have minor differences in their subcellular localization. While $\mathrm{pVHL}^{30}$ is primarily cytosolic and less nuclear, pVHL $^{19}$ is equally distributed between the two compartments [40, 42, 52-55]. pVHL ${ }^{30}$ has also been found to associate with the endoplasmic reticulum (ER), while $\mathrm{pVHL}^{19}$ does not $[40,54]$. The functional significance of $\mathrm{pVHL}^{30}$ associating with the ER is unclear, but may be related to the ability of $\mathrm{pVHL}^{30}$ to bind fibronectin and its requirement for proper extracellular fibronectin matrix assembly $[54,56]$. pVHL has also been found in the mitochondria of rats and may further regulate glucose and fat metabolism by mechanisms additional to its role in the hypoxia-responsive pathway (discussed below) [57].

\section{VEC Ubiquitin Ligase Complex}

pㄴHL associates with elongins $\mathrm{B}$ and $\mathrm{C}, \underline{\mathrm{Cu}} 2$, and RING box protein (Rbx) 1, forming the VEC E3 ubiquitin ligase complex (see fig. 1) [55, 58-65]. VEC functions in conjunction with an E2 ubiquitin-conjugating enzyme to polyubiquitinate proteins which targets them for degradation via the $26 \mathrm{~S}$ proteasome. Cul2 is the scaffold for the $\mathrm{E} 2$ enzyme, $\mathrm{Rbx} 1$, and elongin $\mathrm{C}$ components of the complex [55]. Rbx1 functions to assist in recruiting the E2 [66-68]. Elongin $\mathrm{C}$ bridges Cul2 and the substrate recognition component of the E3 ligase, pVHL (see fig. 1) [69, 70]. pVHL also interacts with the CCT (cytosolic chaperonin-containing $\mathrm{TCP}-1)$ protein-folding complex which promotes proper folding of $\mathrm{pVHL}$ prior to its binding elongin $\mathrm{C}$ [71].

Thus, pVHL consists of two functionally distinct domains: an $\alpha$ domain at its $\mathrm{COOH}$ terminus (residues 156 206) and a $\beta$ domain primarily at its $\mathrm{NH}_{2}$ terminus (residues 63-155 and 207-213; see fig. 1) [70]. The $\alpha$ domain is required for binding elongin $C$, and the $\beta$ domain is the substrate-docking interface for target proteins, including the HIF- $\alpha$ subunits [70]. Mutations in either domain of pVHL have been found in VHL patients and often cluster to the surface residues that contact elongin $\mathrm{C}$ or substrate $[58,72,73]$. This strongly suggests the importance of $\alpha$ and $\beta$ domains for the tumor suppressor function of pVHL.

\section{Hypoxia-Inducible Factors}

\section{Expression of hHIF- $\alpha$ Subunits}

HIF is a heterodimeric transcription factor composed of alpha and beta subunits and is the primary mediator of the cellular hypoxic response [74-77]. There are three HIF- $\alpha$ genes in humans: $h H I F-1 \alpha, h H I F-2 \alpha$ (also known as EPAS1 and MOP2), and $h H I F-3 \alpha$ (see figure 2). The hHIF-1 $\alpha$ tissue expression is ubiquitous and generally weak [71, 78, 79]. Recently, hHIF-1 was shown to be required for myeloid cell infiltration and activation because of its ability to activate the enzymes of glycolysis [80]. While the hHIF-2 $\alpha$ expression is also widespread, there are noticeable differences between tissues [79, 81, 82]. For example, in the mouse, mHIF-2 $\alpha$ is highly expressed in the lung, where it has been implicated in the development of the tubular system, and in vascular endothelial cells, where it is involved in vascular remodeling [83-85]. hHIF-3 $\alpha$ is the least characterized of the hHIF- $\alpha$ subunits and is unique because the gene gives rise to mul- 
Fig. 1. Multiple mechanisms regulate the hypoxia-responsive pathway. Under hypoxic conditions, hHIF- $\alpha$ subunits are stabilized and enter the nucleus via their C-terminal nuclear localization signal (C-NLS). hHIF- $\alpha$ dimerizes with ARNT and binds to the hypoxia-responsive elements (HRE) of target genes, such as VEGF, EPO, and TGF- $\alpha$, to activate transcription. hHIF-1 and hHIF- $2 \alpha$ are also reduced by REF-1/transferrin at a conserved cysteine residue in the $\mathrm{C}$-terminal transactivation domain (C-TAD) which potentiates binding of transcriptional coactivators $\mathrm{CBP} / \mathrm{p} 300$. Under normoxia, hHIF- $\alpha$ subunits are hydroxylated at a conserved proline residue within ODDD by PHD 1-3. The modified hHIF- $\alpha$ subunits are then recognized and bound by pVHL of the VEC E3 ubiquitin ligase complex for polyubiquitination which targets them for degradation via the $26 \mathrm{~S}$ proteasome. In addition, a conserved asparagine residue within the $\mathrm{C}$-terminal transactivation domain (C-TAD) of hHIF- $1 / 2 \alpha$ is hydroxylated by FIH-1 under normoxia which inhibits recruitment of coactivators.

Fig. 2. Domain structure of hHIF- $1 \alpha$, hHIF$2 \alpha$, hHIF-3 $\alpha 1-4$, and mIPAS. Functional domains are illustrated as open boxes, and the double-headed arrow represents the inhibitory domain (ID). bHLH = Basic helixloop-helix; PAS = Per/Arnt/Sim; PAC = PAS-associated C-terminal domain; N/C$\mathrm{TAD}=\mathrm{N} / \mathrm{C}$-terminal transactivation domain; ODDD = oxygen-dependent degradation domain; C-NLS = C-terminal nuclear localization signal; LXXLL = LXXLL motif; LZIP = leucine zipper. $\mathrm{P}, \mathrm{C}, \mathrm{N}$ represent conserved proline, cysteine, and asparagine residues that are modified for hHIF- $\alpha$ regulation.

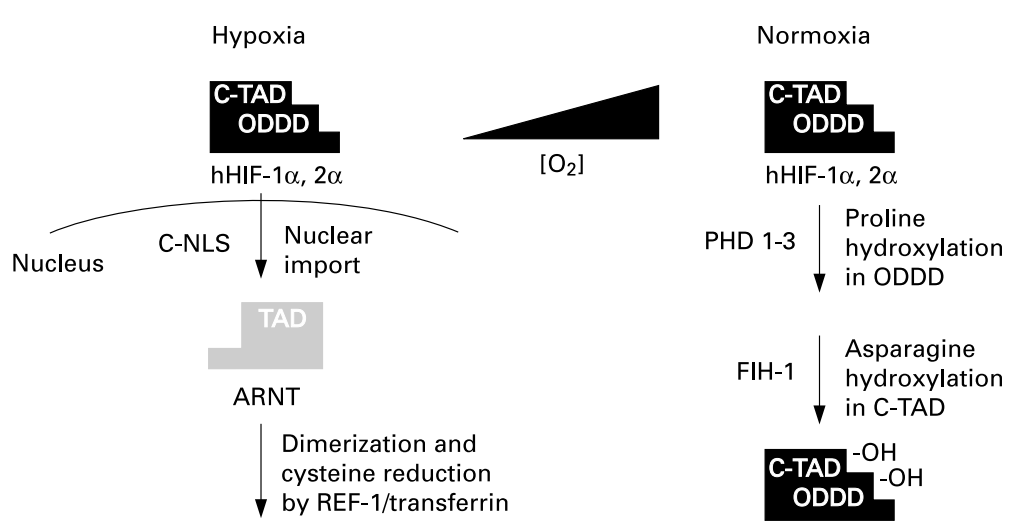

C-TAD-SH

ODDD

Binding to $\mathrm{p} \mathrm{VHL}$ of the VEC complex

$\checkmark$

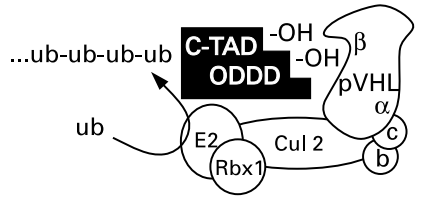

CBP/p300

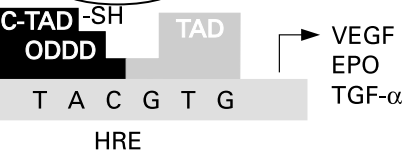

Degradation via the $26 \mathrm{~S}$

$\checkmark$ proteasome

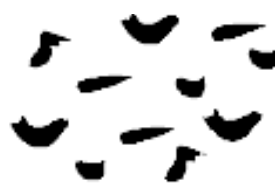

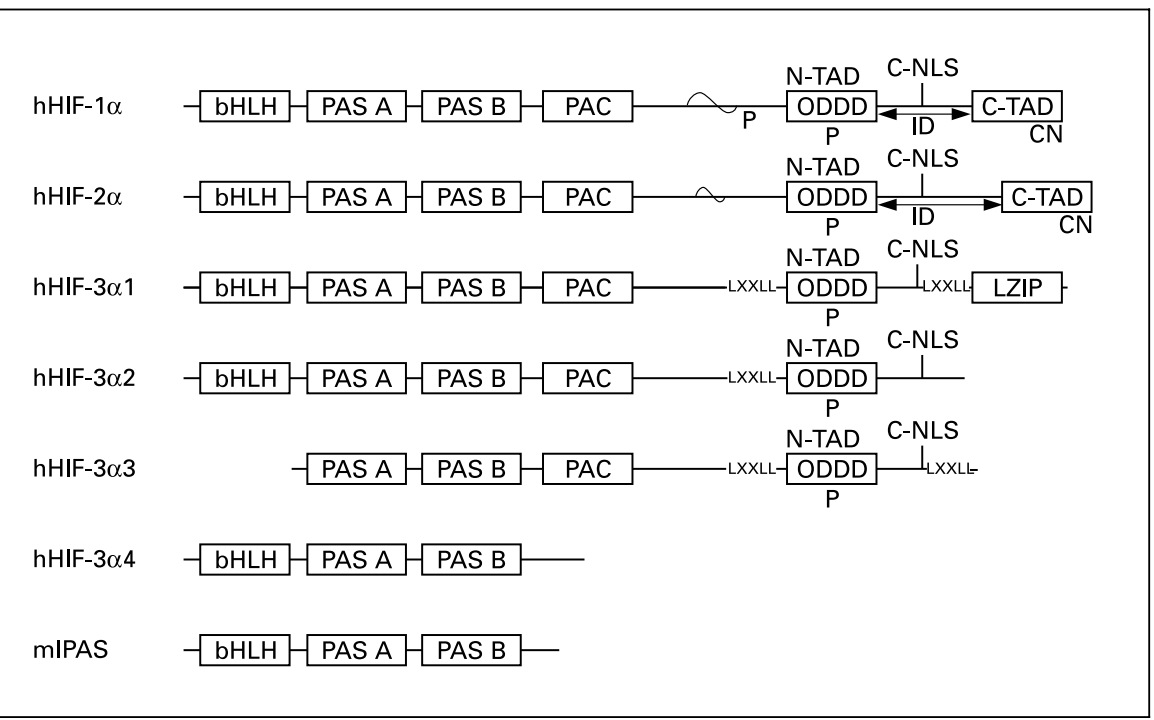


tiple transcripts in both mice and humans (fig. 1) [86, 87] Its expression is highest in heart, placenta, lung, and skeletal muscle and weaker in liver and kidney of humans [86].

\section{hHIF- $\alpha / A R N T$ Dimerization and DNA Binding}

The hHIF- $1 \alpha$ protein is 826 amino acids and approximately $120 \mathrm{kD}$ [88]. hHIF-2 $\alpha$ is 874 amino acids and approximately $115 \mathrm{kD}[81,83]$. hHIF-3 $\alpha 1$ (the longest HIF-3 $\alpha$ isoform) is 668 amino acids and approximately $73 \mathrm{kD}$ (see fig. 2) [86, 89]. hHIF-1 $\alpha$, hHIF-2 $\alpha$, and hHIF$3 \alpha$ possess a basic helix-loop-helix (bHLH), two er/ ARNT/ Sim homology domains (PAS A and PAS B), and a

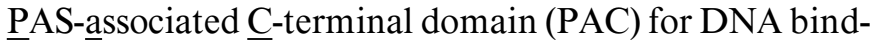
ing and dimerization with hHIF-1 $\beta$ (also known as ARNT; aryl hydrocarbon receptor nuclear translocator; see fig. 2) [83, 90]. ARNT is $91-94 \mathrm{kD}$ and is constitutively expressed [74, 75]. Thus, the regulation of hHIF transcription factors occurs primarily at the level of hHIF- $\alpha$ subunits $[75,91]$. The heterodimeric HIF binds to the hypoxia-responsive element (HRE) within the enhancer of hypoxia-responsive genes [90]. Other members of the PAS family of proteins such as ARNT2 and ARNT3 also interact with hHIF- $\alpha$, although the significance of this diversity is presently unknown $[92,93]$.

\section{Degradation of hHIF- $\alpha$ by VEC under Normoxia}

hHIF- $\alpha$ subunits are labile under normoxia and are degraded after polyubiquitination by the VEC complex [73, 94-99]. The minimum domain that confers instability to hHIF- $\alpha$ has been mapped and appropriately named the oxygen-dependent degradation domain (ODDD; see fig. 2) [99-101]. A proline residue in the conserved LAPYIXMD motif within the ODDD (P564, P531, and P490 in hHIF-1 $\alpha$, hHIF-2 $\alpha$, and hHIF-3 $\alpha 1-3$, respectively) and another conserved proline residue outside of the ODDD (P402 in hHIF-1 $\alpha$ ) are hydroxylated in the presence of oxygen [86, 102-104]. The $\beta$ domain of pVHL specifically recognizes and binds to the prolyl-hydroxylated ODDD (see figure 1) [86, 102-104].

\section{Prolyl Hydroxylase Domain Containing Proteins}

The enzymes prolyl hydroxylase domain containing proteins (PHD) 1, 2, and 3 in humans are responsible for prolyl hydroxylation (see fig. 1) $[105,106]$. PHDs selectively hydroxylate hHIF- $\alpha$ subunits under normoxia, because their activity is dependent on the availability of molecular oxygen $[105,106]$. Therefore, hHIF- $\alpha$ subunits are stabilized under hypoxia [96]. Based on hHIF-1 $\alpha$, there is evidence supporting differential substrate speci- ficity by the three PHD enzymes. All three PHDs are capable of hydroxylating P564, but PHD2 is most active in this capacity [105, 107]. PHD1 and PHD2, but not PHD3, are capable of hydroxylating P402 [105, 107]. Interestingly, PHD2 and PHD3 are transcriptionally upregulated by hypoxia, while PHD1 is constitutively high irrespective of the oxygen level [105, 107, 108]. The hypoxic induction of PHD2 and PHD3 may prepare the cell in advance for rapid hydroxylation of hHIF- $\alpha$, when the normal oxygen tension resumes.

\section{hHIF-3al Has a Unique Domain Structure}

In addition to possessing bHLH, PAS A, PAS B, PAC, and ODDD domains, hHIF-3 31 , but not hHIF-1 $\alpha$ or hHIF-2 $\alpha$, possesses a leucine zipper at its $\mathrm{COOH}$ terminus and two LXXLL motifs flanking the ODDD (see fig. 2) [86]. These may mediate novel DNA binding and protein-protein interactions, respectively. The potential target DNA sequences and proteins that interact singularly with hHIF-3 $\alpha$ via the leucine zipper and LXXLL motifs are currently unknown.

\section{Transactivation Properties of HIF- $\alpha$ Subunits}

$\mathrm{HIF}-1 \alpha$ contains an $\underline{\mathrm{NH}}_{2}$ terminus transactivation domain (N-TAD) and a COOH terminus TAD (C-TAD; see fig. 1 and 2). The C-TAD of hHIF-1 $\alpha$ encompasses residues 786-826 and interacts with the transcriptional coactivators $\underline{\mathrm{c}} \mathrm{AMP}$ response element binding protein (CREB) and $\underline{\mathrm{C} R E B}$ - $\underline{b}$ inding protein (CBP), p300, steroid receptor coactivator (SRC-1), and transcription intermediary factor 2 (TIF-2) for transcriptional activation [82, 109-112]. $\mathrm{CBP} / \mathrm{p} 300, \mathrm{SRC}-1$, and TIF-2 have intrinsic histone acetyltransferase activity. Redox factor 1 (REF-1), a protein with cysteine-reducing activity, also interacts with the CTAD [82]. In conjunction with transferrin, REF-1 reduces a conserved cysteine residue in the C-TAD (YDCEV) of HIF-1/2 $\alpha$ [82]. Cysteine reduction enhances binding of SRC- 1 and $\mathrm{CBP} / \mathrm{p} 300$ and, therefore, transactivation by hHIF-1 [82].

C-TAD is also regulated by oxygen tension through inhibitory hydroxylation of a conserved asparagine residue by the asparagyl-hydroxylase-factor-inhibiting $\underline{\mathrm{HIF}}-1$ (FIH-1; see fig. 1) [113]. Under normoxia, asparagine hydroxylation at residue 803 in hHIF-1 $\alpha$ inhibits binding of $\mathrm{CBP} / \mathrm{p} 300$ by steric hindrance [113]. This residue is conserved in hHIF-2 $\alpha$ at residue 851. Additionally, there is a less well characterized inhibitory domain (ID) between N-TAD and C-TAD that negatively regulates these domains by a mechanism independent of altering stability, but dependent on oxygen tension [114]. 
Table 1. Transcriptional targets of hHIF-1

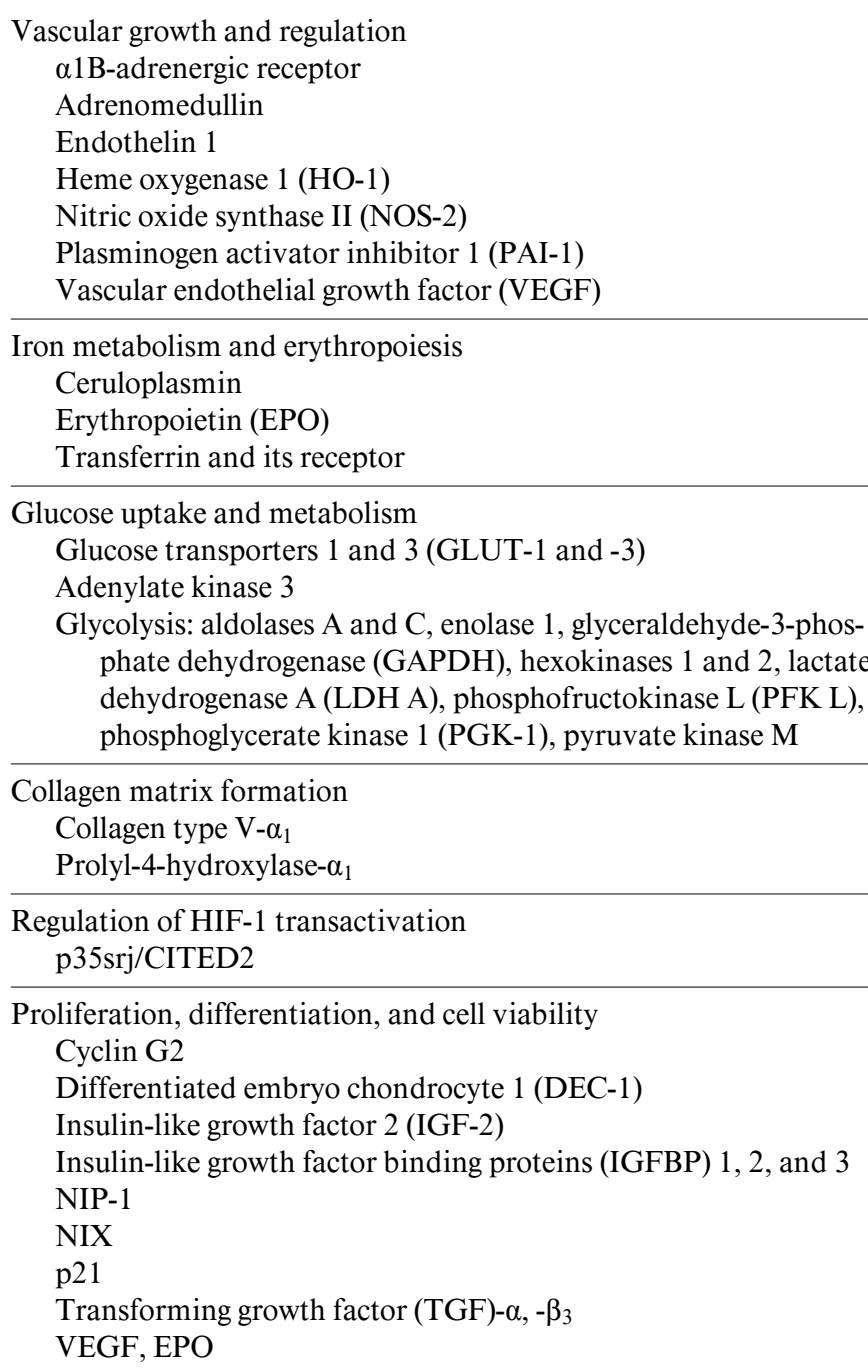

Catecholamine biosynthesis

Tyrosine hydroxylase $(\mathrm{TH})$

Regulation of extracellular $\mathrm{pH}$

Carbonic anhydrases (CA) 9 and 12

For references, refer to Semenza [151] and Maxwell et al. [152]. and hHIF- $2 \alpha$ and before the second LXXLL of hHIF- $3 \alpha 1$. C-NLS is required for the nuclear localization of hHIF$1 \alpha$, hHIF-2 $\alpha$, and hHIF-3 $\alpha$ [115]. Interestingly, while the entire C-NLS is required for hHIF-1 $\alpha$ translocation, either bipartite half of the C-NLS of hHIF-2 $\alpha$ is sufficient for nuclear localization [115]. For hHIF-3 $\alpha$, the minimal NLS required for nuclear translocation has not been determined.

\section{Transcriptional Targets of hHIF-1, hHIF-2, and hHIF-3}

hHIF-1 is an activator of transcription of numerous genes, including those involved in angiogenesis and vascular regulation, erythropoiesis and iron metabolism, glucose transport and glycolysis, collagen matrix formation, proliferation, differentiation, apoptosis, catecholamine biosynthesis, and extracellular $\mathrm{pH}$ regulation (see table 1). hHIF-2 is capable of binding the same HRE elements recognized by hHIF-1, and hence hHIF-2 has the potential to activate hHIF-1-responsive genes [81, 83, 84, 101]. To date, hHIF-2 has been documented to activate VEGF, erythropoietin (EPO), glycolytic enzymes, tyrosine hydroxylase, Flk-1, and Tie-2 [81, 83, 84, 101, 117, 118]. Furthermore, hHIF-2 is reported to have a higher transactivation potential than HIF-1 at some promoters, including those of $E P O$ and $V E G F$ [81]. At the Flk-1 (VEGF-2 receptor) promoter, the Ets transcription factor interacts exclusively with the N-TAD of hHIF-2 $\alpha$ to activate transcription [117]. Correspondingly, the Flk-1 expression on proliferating endothelial cells correlates with the high expression of hHIF-2 $\alpha$, but not hHIF-1 $\alpha$. hHIF-2 is also reported to specifically upregulate the angiopoietin receptor Tie-2, whereas hHIF-1 has no activity at this promoter [83]. hHIF-3 appears to be a relatively weak transcriptional activator of hypoxia-responsive genes $[89,90]$. Whether hHIF-3 has transactivation specificity that is unique from hHIF-1 and/or hHIF-2 is currently unknown.

\section{Dominant-Negative Inhibitor of HIF Transactivation}

Recently, a dominant-negative inhibitor of murine HIF-1 transactivation was identified as an alternatively spliced variant of the mouse $H I F-3 \alpha$ locus ( $m H I F-3 \alpha$ ) and named inhibitory PAS domain protein (mIPAS) [87, 119]. Under normoxia, mIPAS is expressed in the corneal epithelium and the Purkinje cells of the cerebellum [119]. 
Hypoxia-inducible expression of mIPAS through selective splicing of the $m H I F-3 \alpha$ locus has been shown to occur in corneal epithelium, cerebrum, cerebellum, heart, skeletal muscle, and lung [119]. Interestingly, Makino et al. [87] demonstrated that the selective splicing of the $m I P A S$ isoform occurs in the exclusion of full-length $m H I F-3 \alpha$ in heart and lung [87].

Inhibition of angiogenesis in the hypoxic eye is critical in preventing vision impairment. The expression of mIPAS in the corneal epithelium inhibits angiogenesis under hypoxia by limiting the transcription of $V E G F$ [119]. It is now known that mIPAS can dimerize with MHIF-1 $\alpha$, preventing its binding to ARNT and to the HREs of HIFregulated genes including VEGF [119]. Furthermore, implanting mIPAS antisense coated pellets into the eyes of mice disinhibited angiogenesis and thereby implicated mIPAS as the key negative regulator of HIF-mediated VEGF expression in the eye [119]. Significantly, as compared with parental Hepa 1c1c7 cells, Hepa 1c1c7 cells stably transfected with mIPAS produced slower-growing tumors with lower vascular density when implanted into SCID mice [119].

mIPAS has structural homology to hHIF-3a4 splice variant (see fig. 2). Whether hHIF-3 44 is capable of acting as a dominant-negative inhibitor of human HIF-mediated transactivation remains to be determined.

\section{Contribution of HIF to the Development of CC-RCC}

The VHL tumor-suppressor gene is considered the 'gatekeeper' for the development of CC-RCC. The development of CC-RCC in familial VHL disease and sporadic kidney cancer begins with the biallelic inactivation of the $V H L$ locus $[4,30]$. Reintroduction of the wild-type $\mathrm{pVHL}$ into pVHL-/- CC-RCC cell lines suppresses their ability to form tumors in Nude/SCID mice [42, 44]. The ability of VEC to target hHIF-1 $\alpha$ and hHIF- $2 \alpha$ for ubiquitinmediated destruction is thought to be indispensable for the tumor suppressor function of $\mathrm{pVHL}$.

hHIF- $1 \alpha$ and hHIF- $2 \alpha$ are frequently overexpressed in hypoxic regions of solid tumors. Likewise, inordinately high levels of hHIF-1 $\alpha$ and hHIF- $2 \alpha$ are found in CCRCCs devoid of functional pVHL [120]. It follows then that many of the hypoxia-responsive genes are upregulated in most human cancers [121]. For example, CCRCCs are highly vascular due to the overexpression of angiogenic factors such as VEGF. Recently, hHIF-1 $\alpha$ has also been shown to be upregulated in TS CC-RCC [122].
TS CC-RCC tumors are reminiscent of VHL-associated CC-RCC due to their hypervascular phenotype and the overproduction of VEGF [123]. The product of the TSC2 tumor suppressor gene (tuberin) has been shown to inhibit hHIF-1 $\alpha$ via the mammalian target of rapamycin (mToR) and a mToR-independent mechanism [122]. hHIF-regulated TGF- $\alpha$ is an epithelial mitogen that can stimulate the proliferation of primary renal proximal tubular epithelial cells (RPTEC; the suspected origin of CC-RCC) as well as quiescent CC-RCC cells stably expressing pVHL $[124,125]$. RPTEC and CC-RCC express the TGF- $\alpha$ receptor EGFR (endothelial growth factor receptor) [124, 126]. Thus, the TGF- $\alpha /$ EGFR autocrine loop may contribute to CC-RCC tumorigenesis.

The relative contribution of hHIF-2 versus hHIF-1 in $\mathrm{CC}-\mathrm{RCC}$ is an emerging area of research. The introduction of hHIF- $1 \alpha$ mutant that escapes $p$ VHL recognition into CC-RCC cells reconstituted with wild-type pVHL does not produce a tumorigenic phenotype in SCID mice [127]. However, the treatment of these pVHL-restored CC-RCC with hHIF-1 $\alpha$ ODDD peptide that can block pVHL binding to hHIF- $\alpha$ substrates restored the tumorigenic phenotype [127]. This finding suggests that although hHIF- $1 \alpha$ is dispensable, other hHIF- $\alpha$ subunits (or other VEC substrates) are associated with the tumor suppressor function of $\mathrm{pVHL}$. In support of this notion, the importance of hHIF-2 $\alpha$ in CC-RCC tumorigenesis was demonstrated by Kondo et al. [128]. In their study, they used hHIF- $2 \alpha$ that could not be targeted for polyubiquitination by VEC. Unlike hHIF-1 $\alpha$, this stable hHIF- $2 \alpha$ was able to restore the tumor phenotype in CC-RCC cells stably expressing pVHL [128]. This suggests that hHIF-2 $\alpha$ is a major oncogenic player in the progression of CC-RCC.

\section{HIF-Independent Functions of pVHL}

\section{Potential Additional Targets of the VEC Complex}

hHIF- $\alpha$ proteins are the most established substrates of the VEC ubiquitin ligase complex. However, others have been identified. pVHL binds several of the atypical protein kinase $\underline{\mathrm{C}}(\mathrm{aPKC})$ isoforms and may target aPKC $\bar{\lambda}$ for ubiquitin-mediated proteolysis [129]. VEC may also target the VHL-interacting deubiquitinating enzymes (VDU) 1 and 2 for polyubiquitination [130]. pVHL can also interact and target the hyperphosphorylated large subunit of RNA polymerase II (Rpb1) for ubiquitinmediated degradation [131]. Rpb1 and associated Rpb6 both possess an ODDD-like domain which contains a hydroxylation motif for promoting the binding to $\mathrm{pVHL}$ 
[131]. Moreover, Na et al. [132] have shown that pVHL can interact with Rpb7 of RNA polymerase II for proteasomal degradation which suppresses Rpb7-induced $V E G F$ transactivation [132]. Thus, pVHL's ability to inhibit transcription under normoxia by binding to the components of the RNA polymerase II may contribute to its ability to function as a tumor suppressor.

\section{Regulation of the Extracellular Fibronectin Matrix by pVHL}

Dysregulation of the extracellular matrix (ECM) assembly is often associated with solid tumors [133]. VHL-/CC-RCC cells are deficient in proper fibronectin matrix assembly [54]. pVHL has been shown to associate directly with fibronectin to promote normal fibronectin matrix formation [54, 134]. In three-dimensional growth assays, VHL-/- CC-RCC cells appear undifferentiated and form tightly packed spheroids [135]. Reintroduction of pVHL into these cells induces epithelial differentiation and forms loose spheroids. This observation has been attributed to the deposition and formation of fibronectin matrix by CCRCC cells expressing pVHL [54]. pVHL is also required for the formation of $\beta 1$-integrin fibrillar adhesions from classic focal contacts which is required for organizing extracellular fibronectin into fibrillar arrays [56].

In type $2 \mathrm{C}$ VHL disease, $\mathrm{pVHL}$ binding to fibronectin is impaired, while its E3 ubiquitin ligase function is not [134]. Type-2C-causing mutations may represent an oncogenic gain of function for pVHL, because type 1 VHL patients have a low risk of developing pheochromocytomas.

\section{pVHL's Regulation of Matrix Metalloproteinases (MMPs) and Tissue Inhibitors of Metalloproteinases (TIMPS)}

Another consequence of pVHL inactivation is the upregulation of MMPs such as MMP1 [136]. pVHL's negative regulation of MMP1 occurs independent of the hypoxia-responsive pathway [136]. MMPs are important for angiogenesis, morphogenesis, and tissue remodeling and are upregulated during tumor growth and metastasis. The MMP inhibitors TIMPs are upregulated by pVHL independent of the hypoxia-responsive pathway [136]. VHL-/- CC-RCC cells with upregulated MMPs and downregulated TIMPs are more invasive on artificial ECM in response to HGF than their counterparts with reconstituted pVHL [136].

\section{Direct Regulation of Transcription by $p V H L$}

pVHL is capable of regulating the transcription of certain genes independent of the hypoxia-responsive pathway and its ability to regulate RNA polymerase II subunits. pVHL has been shown to sequester the transcription factor SP1, but does not target SP1 for polyubiquitination [137]. This binding represses activity at the proximal promoter of platelet-derived growth factor $\beta$ [138]. As well, pVHL can interact with hHIF-1 at HRE enhancer sequences and recruit the novel transcriptional repressor,

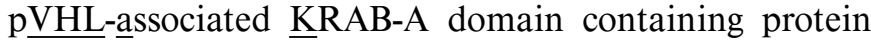
$(\mathrm{VHLaK})[139]$. VHLaK binds $\underline{\mathrm{K} R A B}$-asssociated protein 1 (KAP-1) which recruits histone deacetylase complexes or heterochromatin protein 1 family members for transcriptional repression [140-144]. Interestingly, the VHLaK gene, ZnF197, is located on chromosome 3p21, a common site for translocations found in CC-RCC [145].

\section{pVHL's Regulation of the Cell Cycle}

CC-RCC cells devoid of pVHL overexpress cyclin D1, downregulate the cyclin-dependent kinase inhibitor p27, and do not exit the cell cycle following serum starvation [148-151]. When pVHL is reintroduced into these cells specifically, the cyclin D1 expression is restored such that it is repressed under normoxia and activated during hypoxia [140].

pVHL can also interact with microtubules and stabilize them against depolymerization in vivo [152]. Microtubule polymerization and depolymerization occur during the chromosome division phase of mitosis. Diseaseassociated pVHLs that fail to bind microtubules are primarily type $2 \mathrm{~A}$ mutants which predispose patients to hemangioblastomas and pheochromocytomas, but not CC-RCC [152]. Whether pVHL's role in microtubule depolymerization is important for tumor suppressor activity remains to be determined.

\section{Concluding Remarks}

In summary, the development VHL disease and most CC-RCCs are due to the mutation or inactivation of the VHL tumor suppressor protein pVHL. pVHL is a vital component of an E3 ubiquitin ligase complex called VEC and plays a role of specifying the target to be polyubiquitinated. Polyubiquitin-tagged proteins are subsequently degraded by the common $26 \mathrm{~S}$ proteasome. The targets of VEC are the HIF- $\alpha$ subunits which are part of the heterodimeric transcription factor HIF. Importantly, in the absence of functional pVHL, as in VHL-associated tu- 
mors including CC-RCC, HIF becomes stabilized and inappropriately overexpresses hypoxia-inducible genes such as VEGF, GLUT-1, and EPO. This likely explains why VHL-associated tumors are hypervascular. There are now at least three HIF- $\alpha$ subunits (HIF-1 $\alpha$, HIF-2 $\alpha$, and various HIF- $3 \alpha$ isoforms) that are targeted for $\mathrm{pVHL}$ dependent ubiquitin-mediated destruction. This adds complexity to our current understanding of oxygen-sensing mechanisms and in particular to how hypoxia-inducible genes are ultimately regulated. Continued molecular characterization of the interplay between pVHL and its targets will undoubtedly help shed new insight into the development of CC-RCC and perhaps provide new avenue(s) of anticancer intervention.

\section{Acknowledgements}

We wish to thank the members of the Ohh Lab for their useful discussions. We apologize to those whose work was not cited due to space limitations. This work was supported by the National Cancer Institute of Canada and the Terry Fox Foundation. M.A.M. is the recipient of the NSERC post-graduate scholarship. M.O. is a Canada Research Chair in Molecular Oncology.

\section{References}

1 Wingo PA, Tong T, Bolden S: Cancer statistics, 1995. CA Cancer J Clin 1995;45:8-30.

2 Linehan WM, Lerman MI, Zbar B: Identification of the von Hippel-Lindau (VHL) gene. JAMA 1995;273:564-570.

3 Walther M, Lubensky I, Venzon D, Zbar B, Linehan W: Prevalence of microscopic lesions in grossly normal renal parenchyma from patients with von Hippel-Lindau disease, sporadic renal cell carcinoma and no renal disease: Clinical implications. J Urol 1995;154:20102014.

4 Lubensky IA, Gnarra JR, Bertheau P, Walther MM, Linehan WM, Zhuang Z: Allelic deletions of the VHL gene detected in multiple microscopic clear cell renal lesions in von HippelLindau disease patients. Am J Pathol 1996; 149:2089-2094.

5 Gnarra JR, Tory K, Weng Y, Schmidt L, Wei MH, Li H, Latif F, Liu S, Chen F, Duh FM, et al: Mutations of the VHL tumour suppressor gene in renal carcinoma. Nat Genet 1994;7:8590 .

6 Herman JG, Latif F, Weng Y, Lerman MI, Zbar B, Liu S, Samid D, Duan DS, Gnarra JR, Linehan WM, et al: Silencing of the VHL tumor-suppressor gene by DNA methylation in renal carcinoma. Proc Natl Acad Sci USA 1994;91:9700-9704.

7 Cohen AJ, Li FP, Berg S, Marchetto DJ, Tsai S, Jacobs SC, Brown RS: Hereditary renal-cell carcinoma associated with a chromosomal translocation. N Engl J Med 1979;301:592595.

8 Zbar B, Brauch H, Talmadge C, Linehan M: Loss of alleles of loci on the short arm of chromosome 3 in renal cell carcinoma. Nature 1987;327:721-724

9 Kovacs G, Brusa P, De Riese W: Tissue-specific expression of a constitutional 3;6 translocation: Development of multiple bilateral renal-cell carcinomas. Int J Cancer 1989;43:422427.

10 Choyke PL, Glenn GM, Walther MM, Zbar B, Linehan WM: Hereditary renal cancers. Radiology 2003;226:33-46.
11 Parry L, Maynard JH, Patel A, Clifford SC, Morrissey C, Maher ER, Cheadle JP: Analysis of the TSC 1 and TSC2 genes in sporadic renal cell carcinomas. Br J Cancer 2001;85:12261230.

12 Krymskaya VP: Tumour suppressors hamartin and tuberin: Intracellular signalling. Cell Signal 2003;15:729-739.

13 Schmidt L, Duh F, Chen F, Kishida T, Glenn G, Choyke P, Scherer S, Zhuang Z, Lubensky I, Dean $M$, et al: Germline and somatic mutations in the tyrosine kinase domain of the MET proto-oncogene in papillary renal carcinomas. Nat Genet 1997;16:68-73.

14 Tomlinson IP, Alam NA, Rowan AJ, Barclay E, Jaeger EE, Kelsell D, Leigh I, Gorman P, Lamlum H, Rahman S, et al: Germline mutations in $\mathrm{FH}$ predispose to dominantly inherited uterine fibroids, skin leiomyomata and papillary renal cell cancer. Nat Genet 2002;30:406410.

15 Eng C, Kiuru M, Fernandez MJ, Aaltonen LA: A role for mitochondrial enzymes in inherited neoplasia and beyond. Nat Rev Cancer 2003;3: 193-202.

16 Nickerson ML, Warren MB, Toro JR, Matrosova V, Glenn G, Turner ML, Duray P, Merino M, Choyke P, Pavlovich CP, et al: Mutations in a novel gene lead to kidney tumors, lung wall defects, and benign tumors of the hair follicle in patients with the Birt-Hogg-Dube syndrome. Cancer Cell 2002;2:157-164.

17 Davis CJ Jr, Mostofi FK, Sesterhenn IA: Renal medullary carcinoma: The seventh sickle cell nephropathy. Am J Surg Pathol 1995; 19:1-11.

18 Swartz MA, Karth J, Schneider DT, Rodriguez R, Beckwith JB, Perlman EJ: Renal medullary carcinoma: Clinical, pathologic, immunohistochemical, and genetic analysis with pathogenetic implications. Urology 2002;60:10831089.
19 Lynch HT, Smyrk T: Hereditary nonpolyposis colorectal cancer (Lynch syndrome): An updated review. Cancer 1996;78:1149-1167.

20 Lynch HT, Lynch JF: Hereditary nonpolyposis colorectal cancer. Semin Surg Oncol 2000;18: 305-313.

21 Maher E, Kaelin WG: Von Hippel-Lindau disease. Medicine (Baltimore) 1997;76:381-391.

22 Iliopoulos O, Kaelin WG: Von Hippel-Lindau disease; in Fisher DE (ed): Hereditary Cancer. Clifton, Humana Press, 2000.

23 Maher ER, Yates JR, Harries R, Benjamin C, Harris R, Moore AT, Ferguson-Smith MA: Clinical features and natural history of von Hippel-Lindau disease. Q J Med 1990;77: 1151-1163.

24 Maher ER, Webster AR, Moore AT: Clinical features and molecular genetics of von HippelLindau disease. Ophthalmic Genet 1995;16: 79-84.

25 Ivan M, Kaelin WG Jr: The von Hippel-Lindau tumor suppressor protein. Curr Opin Genet Dev 2001;11:27-34.

26 Richards FM, Webster AR, McMahon R, Woodward ER, Rose S, Maher ER: Molecular genetic analysis of von Hippel-Lindau disease. J Intern Med 1998;243:527-533.

27 Lonser RR, Glenn GM, Walther M, Chew EY, Libutti SK, Linehan WM, Oldfield EH: Von Hippel-Lindau disease. Lancet 2003;361: 2059-2067.

28 Leung SK, Ohh M: Playing tag with HIF: The VHL story. J Biomed Biotechnol 2002;2:131135.

29 Kondo K, Kaelin WG Jr: The von Hippel-Lindau tumor suppressor gene. Exp Cell Res 2001; 264:117-125.

30 Stolle C, Glenn G, Zbar B, Humphrey J, Choyke P, Walther M, Pack S, Hurley K, Andrey C, Klausner R, Linehan W: Improved detection of germline mutations in the von Hippel-Lindau disease tumor suppressor gene. Hum Mutat 1998;12:417-423.

31 Ohh M, Kaelin WG Jr: The von Hippel-Lindau tumour suppressor protein: New perspectives. Mol Med Today 1999;5:257-263. 
32 Chen F, Kishida T, Yao M, Hustad T, Glavac D, Dean M, Gnarra JR, Orcutt ML, Duh FM, Glenn G, et al: Germline mutations in the von Hippel-Lindau disease tumor suppressor gene: Correlations with phenotype. Hum Mutat 1995;5:66-75.

33 Zbar B, Kishida T, Chen F, Schmidt L, Maher ER, Richards FM, Crossey PA, Webster AR, Affara NA, Ferguson-Smith MA, et al: Germline mutations in the von Hippel-Lindau (VHL) gene in families from North America, Europe, and Japan. Hum Mutat 1996;8:348-357.

34 Kaelin WG Jr: Molecular basis of the VHL hereditary cancer syndrome. Nat Rev Cancer 2002;2:673-682.

35 Seizinger BR, Rouleau GA, Ozelius LJ, Lane AH, Farmer GE, Lamiell JM, Haines J, Yuen JW, Collins D, Majoor-Krakauer D, et al: Von Hippel-Lindau disease maps to the region of chromosome 3 associated with renal cell carcinoma. Nature 1988;332:268-269.

36 Latif F, Tory K, Gnarra J, Yao M, Duh FM, Orcutt ML, Stackhouse T, Kuzmin I, Modi W, Geil L, et al: Identification of the von HippelLindau disease tumor suppressor gene. Science 1993;260:1317-1320.

37 Renbaum P, Duh FM, Latif F, Zbar B, Lerman M, Kuzmin I: Isolation and characterization of the full-length $3^{\prime}$ untranslated region of the human von Hippel-Lindau tumor suppressor gene. Hum Genet 1996;98:666-671.

38 Zatyka M, Morrissey C, Kuzmin I, Lerman MI, Latif F, Richards FM, Maher ER: Genetic and functional analysis of the von Hippel-Lindau (VHL) tumour suppressor gene promoter. J Med Genet 2002;39:463-472.

39 Schoenfeld A, Davidowitz EJ, Burk RD: A second major native von Hippel-Lindau gene product, initiated from an internal translation start site, functions as a tumor suppressor. Proc Natl Acad Sci USA 1998;95:8817-8822.

40 Iliopoulos O, Ohh M, Kaelin W: pVHL19 is a biologically active product of the von HippelLindau gene arising from internal translation initiation. Proc Natl Acad Sci USA 1998;95: 11661-11666

41 Blankenship C, Naglich J, Whaley J, Seizinger B, Kley N: Alternate choice of initiation codon produces a biologically active product of the von Hippel Lindau gene with tumor suppressor activity. Oncogene 1999;18:1529-1535.

42 Iliopoulos O, Kibel A, Gray S, Kaelin WG: Tumor suppression by the human von HippelLindau gene product. Nat Med 1995;1:822826.

43 Crossey PA, Richards FM, Foster K, Green JS, Prowse A, Latif F, Lerman MI, Zbar B, Affara NA, Ferguson-Smith MA, et al: Identification of intragenic mutations in the von Hippel-Lindau disease tumor suppressor gene and correlation with disease phenotype. Hum Mol Genet 1994;3:1303-1308.

44 Gnarra JR, Zhou S, Merrill MJ, Wagner J, Krumm A, Papavassiliou E, Oldfield EH Klausner RD, Linehan WM: Post-transcriptional regulation of vascular endothelial growth factor mRNA by the VHL tumor suppressor gene product. Proc Natl Acad Sci USA 1996; 93:10589-10594.
45 Kessler P, Vasavada S, Rackley R, Stackhouse T, Duh F, Latif F, Lerman M, Zbar B, Williams B: Expression of the von Hippel-Lindau tumor suppressor gene, VHL, in human fetal kidney and during mouse embryogenesis. Mol Med 1995;1:457-466.

46 Richards F, Schofield P, Fleming S, Maher E: Expression of the von Hippel-Lindau disease tumour suppressor gene during human embryogenesis. Hum Mol Genet 1996;5:639644.

47 Gnarra J, Ward J, Porter F, Wagner J, Devor D, Grinberg A, Emmert-Buck M, Westphal H, Klausner R, Linehan W: Defective placental vasculogenesis causes embryonic lethality in VHL-deficient mice. Proc Natl Acad Sci USA 1997;94:9102-9107.

48 Haase VH, Glickman JN, Socolovsky M, Jaenisch R: Vascular tumors in livers with targeted inactivation of the von Hippel-Lindau tumor suppressor. Proc Natl Acad Sci USA 2001;98: 1583-1588.

49 Lee JY, Dong SM, Park WS, Yoo NJ, Kim CS, Jang JJ, Chi JG, Zbar B, Lubensky I, Linehan $\mathrm{W}$, et al: Loss of heterozygosity and somatic mutations of the VHL tumor suppressor gene in sporadic cerebellar hemangioblastomas. Cancer Res 1998;58:504-508.

50 Vortmeyer A, Gnarra J, Emmert-Buck M, Katz D, Linehan W, Oldfield E, Zhuang Z: Von Hippel-Lindau gene deletion detected in the stromal cell component of a cerebellar hemangioblastoma associated with von Hippel-Lindau disease. Hum Pathol 1997;28:540-543.

51 Lach B, Gregor A, Rippstein P, Omulecka A: Angiogenic histogenesis of stromal cells in hemangioblastoma: Ultrastructural and immunohistochemical study. Ultrastruct Pathol 1999; 23:299-310.

52 Corless CL, Kibel A, Iliopoulos O, Kaelin WG Jr: Immunostaining of the von Hippel-Lindau gene product ( $\mathrm{pVHL}$ ) in normal and neoplastic human tissues. Hum Pathol 1997;28:459-464.

53 Los M, Jansen GH, Kaelin WG, Lips CJ, Blijham GH, Voest EE: Expression pattern of the von Hippel-Lindau protein in human tissues. Lab Invest 1996;75:231-238.

54 Ohh M, Yauch RL, Lonergan KM, Whaley JM, Stemmer-Rachamimov AO, Louis DN, Gavin BJ, Kley N, Kaelin WG Jr, Iliopoulos O: The von Hippel-Lindau tumor suppressor protein is required for proper assembly of an extracellular fibronectin matrix. Mol Cell 1998;1:959-968.

55 Pause A, Lee S, Worrell RA, Chen DY, Burgess WH, Linehan WM, Klausner RD: The von Hippel-Lindau tumor suppressor gene product forms a stable complex with human CUL-2, a member of the Cdc53 family of proteins. Proc Natl Acad Sci USA 1997;94:2156-2161.

56 Esteban-Barragan MA, Avila P, Alvarez-Tejado M, Gutierrez MD, Garcia-Pardo A, Sanchez-Madrid F, Landazuri MO: Role of the von Hippel-Lindau tumor suppressor gene in the formation of beta1-integrin fibrillar adhesions. Cancer Res 2002;62:2929-2936.
57 Shiao YH, Resau JH, Nagashima K, Anderson LM, Ramakrishna G: The von Hippel-Lindau tumor suppressor targets to mitochondria. Cancer Res 2000;60:2816-2819.

58 Kibel A, Iliopoulos O, DeCaprio JA, Kaelin WG Jr: Binding of the von Hippel-Lindau tumor suppressor protein to elongins B and C. Science 1995;269:1444-1446.

59 Duan DR, Pause A, Burgess W, Aso T, Chen DY, Garrett KP, Conaway RC, Conaway JW, Linehan WM, Klausner RD: Inhibition of transcriptional elongation by the VHL tumor suppressor protein. Science 1995;269:1402-1406.

60 Lonergan KM, Iliopoulos O, Ohh M, Kamura T, Conaway RC, Conaway JW, Kaelin WG Jr: Regulation of hypoxia-inducible mRNAs by the von Hippel-Lindau tumor suppressor protein requires binding to complexes containing elongins B/C and Cul2. Mol Cell Biol 1998;18: 732-741.

61 Deshaies R: SCF and Cullin/Ring H2-based ubiquitin ligases. Annu Rev Cell Dev Biol 1999;15:435-467.

62 Ciechanover A, Orian A, Schwartz AL: Ubiquitin-mediated proteolysis: Biological regulation via destruction. Bioessays 2000;22:442-451.

63 Pause A, Peterson B, Schaffar G, Stearman R, Klausner R: Studying interactions of four proteins in the yeast two-hybrid system: Structural resemblance of the $\mathrm{pVHL} /$ elongin $\mathrm{BC} / \mathrm{hCUL}-2$ complex with the ubiquitin ligase complex SKP1/cullin/F-box protein. Proc Natl Acad Sci USA 1999;96:9533-9538.

64 Kamura T, Koepp DM, Conrad MN, Skowyra D, Moreland RJ, Iliopoulos O, Lane WS, Kaelin WG Jr, Elledge SJ, Conaway RC, et al: Rbx 1, a component of the VHL tumor suppressor complex and SCF ubiquitin ligase. Science 1999;284:657-661.

65 Kishida T, Stackhouse TM, Chen F, Lerman MI, Zbar B: Cellular proteins that bind the von Hippel-Lindau disease gene product: Mapping of binding domains and the effect of missense mutations. Cancer Res 1995;55:4544-4548.

66 Ohta T, Michel JJ, Schottelius AJ, Xiaong Y: ROC1, a homolog of APC11, represents a family of cullin partners with an associated ubiquitin ligase activity. Mol Cell 1999;3:535-541.

67 Tan P, Fuchs SY, Chen A, Wu K, Gomez C, Ronai Z, Pan ZQ: Recruitment of a ROC1CUL1 ubiquitin ligase by Skp1 and HOS to catalyze the ubiquitination of 1 RBBB. Mol Cell 1999;3:527-533.

68 Skowyra D, Koepp DM, Kamura T, Conrad $\mathrm{MN}$, Conaway RC, Conaway JW, Elledge SJ, Harper JW: Reconstitution of G1 cyclin ubiquitination with complexes containing SCFGrr1 and Rbx1. Science 1999;284:662665.

69 Bai C, Sen P, Hofmann K, Ma L, Goebl M, Harper JW, Elledge SJ: SKP1 connects cell cycle regulators to the ubiquitin proteolysis machinery through a novel motif, the F-box. Cell 1996;86:263-274.

70 Stebbins CE, Kaelin WG Jr, Pavletich NP: Structure of the VHL-elonginC-elonginB complex: Implications for VHL tumor suppressor function. Science 1999;284:455-461. 
71 Hansen WJ, Ohh M, Moslehi J, Kondo K, Kaelin WG Jr, Welch WJ: Diverse effects of mutations in exon II of the von Hippel-Lindau (VHL) tumor suppressor gene on the interaction of pVHL with the cytosolic chaperonin and pVHL-dependent ubiquitin ligase activity. Mol Cell Biol 2002;22:1947-1960.

72 Ohh M, Takagi Y, Aso T, Stebbins C, Pavletich N, Zbar B, Conaway R, Conaway J, Kaelin W Jr: Synthetic peptides define critical contacts between elongin $\mathrm{C}$, elongin $\mathrm{B}$, and the von Hippel-Lindau protein. J Clin Invest 1999;104: 1583-1591.

73 Ohh M, Park CW, Ivan M, Hoffman MA, Kim TY, Huang LE, Chau V, Kaelin WG Jr: Ubiquitination of HIF requires direct binding to the von Hippel-Lindau protein beta domain Nat Cell Biol 2000;2:423-427.

74 Semenza G: Regulation of mammalian $\mathrm{O}_{2}$ homeostasis by hypoxia-inducible factor 1 . Annu Rev Cell Dev Biol 1999;15:551-578.

75 Semenza G: Perspectives on oxygen sensing. Cell 1999;98:281-284.

76 Wenger R: Mammalian oxygen sensing, signalling and gene regulation. J Exp Biol 2000; 203:1253-1263.

77 Zhu H, Bunn F: Oxygen sensing and signaling: Impact on the regulation of physiologically important genes. Respir Physiol 1999;115:239_ 247.

78 Wiener CM, Booth G, Semenza GL: In vivo expression of mRNAs encoding hypoxia-inducible factor 1. Biochem Biophys Res Commun 1996;225:485-488.

79 Hogenesch JB, Chan WK, Jackiw VH, Brown RC, Gu YZ, Pray-Grant M, Perdew GH, Bradfield CA: Characterization of a subset of the basic-helix-loop-helix-PAS superfamily that interacts with components of the dioxin signaling pathway. J Biol Chem 1997;272:8581-8593.

80 Cramer T, Yamanishi Y, Clausen BE, Forster I, Pawlinski R, Mackman N, Haase VH, Jaenisch R, Corr M, Nizet V, et al: HIF-1alpha is essential for myeloid cell-mediated inflammation. Cell 2003;112:645-657.

81 Wiesener MS, Turley H, Allen WE, Willam C, Eckardt KU, Talks KL, Wood SM, Gatter KC, Harris AL, Pugh CW, et al: Induction of endothelial PAS domain protein-1 by hypoxia: Characterization and comparison with hypoxia-inducible factor-1alpha. Blood 1998;92:2260-2268.

82 Ema M, Hirota K, Mimura J, Abe H, Yodoi J, Sogawa K, Poellinger L, Fujii-Kuriyama Y: Molecular mechanisms of transcription activation by HLF and HIFlalpha in response to hypoxia: Their stabilization and redox signalinduced interaction with $\mathrm{CBP} / \mathrm{p} 300$. EMBO J 1999; 18:1905-1914.

83 Tian H, McKnight SL, Russell DW: Endothelial PAS domain protein 1 (EPAS1), a transcription factor selectively expressed in endothelial cells. Genes Dev 1997;11:72-82.

84 Ema M, Taya S, Yokotani N, Sogawa K, Matsuda Y, Fujii-Kuriyama Y: A novel bHLHPAS factor with close sequence similarity to hypoxia-inducible factor 1alpha regulates the VEGF expression and is potentially involved in lung and vascular development. Proc Natl Acad Sci USA 1997;94:4273-4278.
85 Peng J, Zhang L, Drysdale L, Fong GH: The transcription factor EPAS-1/hypoxia-inducible factor 2alpha plays an important role in vascular remodeling. Proc Natl Acad Sci USA 2000; 97:8386-8391.

86 Maynard MA, Qi H, Chung J, Lee EH, Kondo Y, Hara S, Conaway RC, Conaway JW, Ohh M: Multiple splice variants of the human HIF3alpha locus are targets of the VHL E3 ubiquitin ligase complex. J Biol Chem 2003;278: 11032-11040.

87 Makino Y, Kanopka A, Wilson WJ, Tanaka H, Poellinger L: Inhibitory PAS domain protein (IPAS) is a hypoxia-inducible splicing variant of the hypoxia-inducible factor-3alpha locus. J Biol Chem 2002;277:32405-32408.

88 Wang GL, Semenza GL: Purification and characterization of hypoxia-inducible factor 1 . J Biol Chem 1995;270:1230-1237.

89 Hara S, Hamada J, Kobayashi C, Kondo Y, Imura $\mathrm{N}$ : Expression and characterization of hypoxia-inducible factor (HIF)-3alpha in human kidney: Suppression of HIF-mediated gene expression by HIF-3alpha. Biochem Biophys Res Commun 2001;287:808-813.

$90 \mathrm{Gu}$ YZ, Moran SM, Hogenesch JB, Wartman L, Bradfield CA: Molecular characterization and chromosomal localization of a third alphaclass hypoxia inducible factor subunit, HIF3alpha. Gene Expr 1998; 7:205-213.

91 Semenza GL: HIF-1, O , and the 3 PHDs: How animal cells signal hypoxia to the nucleus [letter; comment]. Cell 2001;107:1-3.

92 Hirose K, Morita M, Ema M, Mimura J, Hamada H, Fujii H, Saijo Y, Gotoh O, Sogawa K, Fujii-Kuriyama Y: cDNA cloning and tissuespecific expression of a novel basic helix-loophelix/PAS factor (Arnt2) with close sequence similarity to the aryl hydrocarbon receptor nuclear translocator (Arnt). Mol Cell Biol 1996; 16:1706-1713.

93 Takahata S, Sogawa K, Kobayashi A, Ema M, Mimura J, Ozaki N, Fujii-Kuriyama Y: Transcriptionally active heterodimer formation of an Arnt-like PAS protein, Arnt3, with HIF-1 $\alpha$, HLF, and clock. Biochem Biophys Res Commun 1998;248:789-794.

94 Cockman M, Masson N, Mole D, Jaakkola P, Chang G, Clifford S, Maher E, Pugh C, Ratcliffe P, Maxwell P: Hypoxia inducible factoralpha binding and ubiquitylation by the von Hippel-Lindau tumor suppressor protein. J Biol Chem 2000;275:25733-25741.

95 Tanimoto K, Makino Y, Pereira T, Poellinger L: Mechanism of regulation of the hypoxiainducible factor-1alpha by the von Hippel-Lindau tumor suppressor protein. EMBO J 2000; 19:4298-4309.

96 Sutter C, Laughner E, Semenza G: Hypoxiainducible factor lalpha protein expression is controlled by oxygen-regulated ubiquitination that is disrupted by deletions and missense mutations. Proc Natl Acad Sci USA 2000;97: 4748-4753.
97 Kallio P, Wilson W, O’Brien S, Makino Y, Poellinger L: Regulation of the hypoxia-inducible transcription factor 1alpha by the ubiquitin-proteasome pathway. J Biol Chem 1999;274:6519-6525.

98 Salceda S, Caro J: Hypoxia-inducible factor 1alpha (HIF-1alpha) protein is rapidly degraded by the ubiquitin-proteasome system under normoxic conditions: Its stabilization by hypoxia depends on redox-induced changes. J Biol Chem 1997;272:2264222647.

99 Huang LE, Gu J, Schau M, Bunn HF: Regulation of hypoxia-inducible factor 1 alpha is mediated by an $\mathrm{O}_{2}$-dependent degradation domain via the ubiquitin-proteasome pathway. Proc Natl Acad Sci USA 1998;95:79877992.

100 Srinivas V, Zhang L, Zhu X, Caro J: Characterization of an oxygen/redox-dependent degradation domain of hypoxia-inducible factor alpha (HIF-alpha) proteins. Biochem Biophys Res Commun 1999;260:557-561.

101 O'Rourke J, Tian YM, Ratcliffe PJ, Pugh $\mathrm{CW}$ : Oxygen-regulated and transactivation domains in endothelial PAS protein 1: Comparison with hypoxia-inducible factor- $1 \alpha$. J Biol Chem 1999;274:2060-2071.

102 Ivan M, Kondo K, Yang H, Kim W, Valiando J, Ohh M, Salic A, Asara JM, Lane WS, Kaelin WG Jr: HIFalpha targeted for VHL-mediated destruction by proline hydroxylation: Implications for $\mathrm{O}_{2}$ sensing. Science 2001; 292:464-468.

103 Jaakkola P, Mole DR, Tian YM, Wilson MI, Gielbert J, Gaskell SJ, Kriegsheim A, Hebestreit HF, Mukherji M, Schofield CJ, et al: Targeting of HIF-alpha to the von HippelLindau ubiquitylation complex by $\mathrm{O}_{2}$-regulated prolyl hydroxylation. Science 2001;292: 468-472.

104 Masson N, Willam C, Maxwell PH, Pugh $\mathrm{CW}$, Ratcliffe PJ: Independent function of two destruction domains in hypoxia-inducible factor-alpha chains activated by prolyl hydroxylation. EMBO J 2001;20:5197-5206.

105 Epstein AC, Gleadle JM, McNeill LA, Hewitson KS, O'Rourke J, Mole DR, Mukherji M, Metzen E, Wilson MI, Dhanda A, et al: C. elegans EGL-9 and mammalian homologs define a family of dioxygenases that regulate HIF by prolyl hydroxylation [see comments]. Cell 2001;107:43-54.

106 Bruick RK, McKnight SL: A conserved family of prolyl-4-hydroxylases that modify HIF. Science 2001;294:1337-1340.

107 Huang J, Zhao Q, Mooney SM, Lee FS: Sequence determinants in hypoxia-inducible factor-1alpha for hydroxylation by the prolyl hydroxylases PHD1, PHD2, and PHD3. J Biol Chem 2002;277:39792-39800.

108 D'Angelo G, Duplan E, Boyer N, Vigne P, Frelin C: Hypoxia up-regulates prolyl hydroxylase activity: A feedback mechanism that limits HIF-1 responses during reoxygenation. J Biol Chem 2003;278:38183-38187. 
109 Pugh C, O’Rourke J, Nagao M, Gleadle J, Ratcliffe P: Activation of hypoxia-inducible factor-1: Definition of regulatory domains within the alpha subunit. J Biol Chem 1997; 272:11205-11214.

110 Kallio PJ, Okamoto K, O’Brien S, Carrero P Makino Y, Tanaka H, Poellinger L: Signal transduction in hypoxic cells: Inducible nuclear translocation and recruitment of the $\mathrm{CBP} / \mathrm{p} 300$ coactivator by the hypoxia-inducible factor-1alpha. EMBO J 1998;17:65736586.

111 Carrero P, Okamoto K, Coumailleau P, O'Brien S, Tanaka H, Poellinger L: Redoxregulated recruitment of the transcriptional coactivators CREB-binding protein and SRC1 to hypoxia-inducible factor 1alpha. Mol Cell Biol 2000;20:402-415.

112 Arany Z, Huang LE, Eckner R, Bhattacharya $\mathrm{S}$, Jiang C, Goldberg MA, Bunn HF, Livingston DM: An essential role for p300/CBP in the cellular response to hypoxia. Proc Natl Acad Sci USA 1996;93:12969-12973.

113 Lando D, Peet DJ, Whelan DA, Gorman JJ, Whitelaw ML: Asparagine hydroxylation of the HIF transactivation domain a hypoxic switch. Science 2002;295:858-861.

114 Jiang BH, Zheng JZ, Leung SW, Roe R, Semenza GL: Transactivation and inhibitory domains of hypoxia-inducible factor $1 \alpha$. J Biol Chem 1997;272:19253-19260.

115 Luo JC, Shibuya M: A variant of nuclear localization signal of bipartite-type is required for the nuclear translocation of hypoxia inducible factors (1alpha, 2alpha and 3alpha). Oncogene 2001;20:1435-1444.

116 Ikuta T, Eguchi H, Tachibana T, Yoneda Y, Kawajiri K: Nuclear localization and export signals of the human aryl hydrocarbon receptor. J Biol Chem 1998;273:2895-2904.

117 Elvert G, Kappel A, Heidenreich R, Englmeier U, Lanz S, Acker T, Rauter M, Plate K, Sieweke M, Breier G, et al: Cooperative interaction of hypoxia-inducible factor-2alpha (HIF-2alpha ) and Ets-1 in the transcriptional activation of vascular endothelial growth factor receptor-2 (Flk-1). J Biol Chem 2003;278: 7520-7530.

118 Schnell PO, Ignacak ML, Bauer AL, Striet JB, Paulding WR, Czyzyk-Krzeska MF: Regulation of tyrosine hydroxylase promoter activity by the von Hippel-Lindau tumor suppressor protein and hypoxia-inducible transcription factors. J Neurochem 2003;85:483-491.

119 Makino Y, Cao R, Svensson K, Bertilsson G, Asman M, Tanaka H, Cao Y, Berkenstam A, Poellinger L: Inhibitory PAS domain protein is a negative regulator of hypoxia-inducible gene expression. Nature 2001;414:550-554.

120 Turner KJ, Moore JW, Jones A, Taylor CF Cuthbert-Heavens D, Han C, Leek RD, Gatter KC, Maxwell PH, Ratcliffe PJ, et al: Expression of hypoxia-inducible factors in human renal cancer: Relationship to angiogenesis and to the von Hippel-Lindau gene mutation. Cancer Res 2002;62:2957-2961.
121 Maxwell P, Weisner M, Chang GW, Clifford S, Vaux E, Pugh C, Maher E, Ratcliffe P: The von Hippel-Lindau gene product is necessary for oxgyen-dependent proteolysis of hypoxiainducible factor $\alpha$ subunits. Nature 1999;399: 271-275.

122 Brugarolas JB, Vazquez F, Reddy A, Sellers WR, Kaelin WG Jr: TSC2 regulates VEGF through mTOR-dependent and -independent pathways. Cancer Cell 2003;4:147-158.

123 Nguyen-Vu PA, Fackler I, Rust A, DeClue JE, Sander CA, Volkenandt M, Flaig M, Yeung RS, Wienecke R: Loss of tuberin, the tuberous-sclerosis-complex-2 gene product is associated with angiogenesis. J Cutan Pathol 2001;28:470-475.

124 de Paulsen N, Brychzy A, Fournier MC, Klausner RD, Gnarra JR, Pause A, Lee S: Role of transforming growth factor-alpha in von Hippel-Lindau (VHL)(-/-) clear cell renal carcinoma cell proliferation: A possible mechanism coupling VHL tumor suppressor inactivation and tumorigenesis. Proc Natl Acad Sci USA 2001;98:1387-1392.

125 Knebelmann B, Ananth S, Cohen H, Sukhatme V: Transforming growth factor alpha is a target for the von Hippel-Lindau tumor suppressor. Cancer Res 1998;58:226-231.

126 Humes H, Beals T, Cieslinski D, Sanchez I, Page T: Effects of transforming growth factorbeta, transforming growth factor-alpha, and other growth factors on renal proximal tubule cells. Lab Invest 1991;64:538-545.

127 Maranchie JK, Vasselli JR, Riss J, Bonifacino JS, Linehan WM, Klausner RD: The contribution of VHL substrate binding and HIF1-T to the phenotype of VHL loss in renal cell carcinoma. Cancer Cell 2002;1:247-255.

128 Kondo K, Klco J, Nakamura E, Lechpammer M, Kaelin WG Jr: Inhibition of HIF is necessary for tumor suppression by the von HippelLindau protein. Cancer Cell 2002;1:237-246.

129 Okuda H, Hirai S, Takaki Y, Kamada M, Baba M, Sakai N, Kishida T, Kaneko S, Yao $\mathrm{M}$, Ohno S, et al: Direct interaction of the beta-domain of VHL tumor suppressor protein with the regulatory domain of atypical PKC isotypes. Biochem Biophys Res Commun 1999;263:491-497.

130 Li Z, Na X, Wang D, Schoen SR, Messing EM, Wu G: Ubiquitination of a novel deubiquitinating enzyme requires direct binding to von Hippel-Lindau tumor suppressor protein. J Biol Chem 2002;277:4656-4662.

131 Kuznetsova AV, Meller J, Schnell PO, Nash JA, Ignacak ML, Sanchez Y, Conaway JW, Conaway RC, Czyzyk-Krzeska MF: Von Hippel-Lindau protein binds hyperphosphorylated large subunit of RNA polymerase II through a proline hydroxylation motif and targets it for ubiquitination. Proc Natl Acad Sci USA 2003;100:2706-2711.

$132 \mathrm{Na}$ X, Duan HO, Messing EW, Schoen SR, Ryan CK, di Sant'Agnese PA, Golemis EA, Wu G: Identification of the RNA polymerase II subunit hsRPB7 as a novel target of the von Hippel-Lindau protein. EMBO J 2003;22: 4249-4259.
133 Hynes R: Integrins: Versatility, modulation, and signalling in cell adhesion. Cell 1992;69: 11-25.

134 Hoffman MA, Ohh M, Yang H, Klco JM, Ivan M, Kaelin WG Jr: Von Hippel-Lindau protein mutants linked to type $2 \mathrm{C}$ VHL disease preserve the ability to downregulate HIF. Hum Mol Genet 2001;10:1019-1027.

135 Lieubeau-Teillet B, Rak J, Jothy S, Iliopoulos O, Kaelin W, Kerbel R: Von Hippel-Lindau gene-mediated growth suppression and induction of differentiation in renal cell carcinoma cells grown as multicellular tumor spheroids. Cancer Res 1998;58:4957-4962.

136 Koochekpour S, Jeffers M, Wang P, Gong C, Taylor G, Roessler L, Stearman R, Vasselli J, Stetler-Stevenson W, Kaelin W Jr, et al: The von Hippel-Lindau tumor suppressor gene inhibits hepatocyte growth factor/scatter factorinduced invasion and branching morphogenesis in renal carcinoma cells. Mol Cell Biol 1999; 19:5902-5912.

137 Cohen H, Zhou M, Welsh A, Zarghamee S, Scholz H, Mukhopadhyay D, Kishida T, Zbar B, Knebelmann B, Sukhatme V: An important von Hippel-Lindau tumor suppressor domain mediates Sp1-binding and self-association. Biochem Biophys Res Commun 1999; 266:43-50.

138 Rafty LA, Khachigian LM: Von Hippel-Lindau tumor suppressor protein represses platelet-derived growth factor B-chain gene expression via the $\mathrm{Sp} 1$ binding element in the proximal PDGF-B promoter. J Cell Biochem 2002;85:490-495.

139 Li Z, Wang D, Na X, Schoen SR, Messing EM, Wu G: The VHL protein recruits a novel KRAB-A domain protein to repress HIF-1alpha transcriptional activity. EMBO J 2003; 22:1857-1867.

140 Kim SS, Chen YM, O'Leary E, Witzgall R, Vidal M, Bonventre JV: A novel member of the RING finger family, KRIP-1, associates with the KRAB-A transcriptional repressor domain of zinc finger proteins. Proc Natl Acad Sci USA 1996;93:15299-15304.

141 Friedman JR, Fredericks WJ, Jensen DE, Speicher DW, Huang XP, Neilson EG, Rauscher F Jr: KAP-1, a novel corepressor for the highly conserved KRAB repression domain. Genes Dev 1996;10:2067-2078.

142 Moosmann P, Georgiev O, Le Douarin B, Bourquin JP, Schaffner W: Transcriptional repression by RING finger protein TIF1 beta that interacts with the KRAB repressor domain of KOX1. Nucleic Acids Res 1996;24: 4859-4867.

143 Underhill C, Qutob MS, Yee SP, Torchia J: A novel nuclear receptor corepressor complex, $\mathrm{N}-\mathrm{CoR}$, contains components of the mammalian SWI/SNF complex and the corepressor KAP-1. J Biol Chem 2000;275:4046340470 . 
144 Lechner MS, Begg GE, Speicher DW, Rauscher FJ 3rd: Molecular determinants for targeting heterochromatin protein 1-mediated gene silencing: Direct chromoshadow domain-KAP-1 corepressor interaction is essential. Mol Cell Biol 2000;20:6449-6465.

145 van den Berg A, Dijkhuizen T, Draaijers TG, Hulsbeek MM, Maher ER, van den Berg E, Storkel S, Buys CH: Analysis of multiple renal cell adenomas and carcinomas suggests allelic loss at 3 p2 1 to be a prerequisite for malignant development. Genes Chromosomes Cancer 1997; 19:228-232.

146 Semenza GL: HIF-1: Mediator of physiological and pathophysiological responses to hypoxia. J Appl Physiol 2000;88:1474-1480.

147 Maxwell PH, Pugh CW, Ratcliffe PJ: Activation of the HIF pathway in cancer. Curr Opin Genet Dev 2001;11:293-299.
148 Zatyka M, da Silva NF, Clifford SC, Morris MR, Wiesener MS, Eckardt KU, Houlston RS, Richards FM, Latif F, Maher ER: Identification of cyclin D1 and other novel targets for the von Hippel-Lindau tumor suppressor gene by expression array analysis and investigation of cyclin D1 genotype as a modifier in von Hippel-Lindau disease. Cancer Res 2002; 62:3803-3811.

149 Pause A, Lee S, Lonergan KM, Klausner RD: The von Hippel-Lindau tumor suppressor gene is required for cell cycle exit upon serum withdrawal. Proc Natl Acad Sci USA 1998; 95:993-998.
150 Kim M, Katayose Y, Li Q, Rakkar A, Li Z, Hwang S, Katayose D, Trepel J, Cowan K, Seth P: Recombinant adenovirus expressing von Hippel-Lindau-mediated cell cycle arrest is associated with the induction of cyclindependent kinase inhibitor p27Kip1. Biochem Biophys Res Commun 1998;253:672677.

151 Bindra RS, Vasselli JR, Stearman R, Linehan WM, Klausner RD: VHL-mediated hypoxia regulation of cyclin D1 in renal carcinoma cells. Cancer Res 2002;62:3014-3019.

152 Hergovich A, Lisztwan J, Barry R, Ballschmieter P, Krek W: Regulation of microtubule stability by the von Hippel-Lindau tumour suppressor protein pVHL. Nat Cell Biol 2003;5:64-70. 